\title{
PENGURANGAN RISIKO MUSCULOSKELETAL DISORDERS PADA AREA MESIN LASER PERFORATOR DI PERUSAHAAN ROKOK MENGGUNAKAN OWAS DAN QFD
}

\author{
Hery Hamdi Azwir*1, Fikri Aswan', Hirawati Oemar² \\ ${ }^{1}$ Program Studi Teknik Industri, Fakultas Teknik, Universitas Presiden \\ Jababeka, Cikarang, Bekasi, Indonesia 17530 \\ ${ }^{2}$ Program Studi Teknik Industri, Fakultas Teknik, Universitas Islam Bandung, \\ Bandung, Indonesia 40132
}

\begin{abstract}
Abstrak
Di dalam perusahaan produksi rokok ini terdapat sebuah mesin laser perforator. Setelah pemasangan mesin laser perforator 50 timbul masalah yang berhubungan dengan gangguan muskuloskeletal. Saat dilakukan wawancara, operator mengeluhkan adanya nyeri punggung bawah karena penanganan material dilakukan secara manual. Setelah dilakukan analisis dengan metode OWAS pada dua kegiatan bongkar muat ditemukan masalah yang berhubungan dengan gangguan muskuloskeletal. Dari hasil analisis ditemukan bahwa aktivitas pemuatan (loading) dikategorikan sebagai tindakan korektif 3 artinya postur tubuh berpengaruh sangat merugikan pada sistem muskuloskeletal, sedangkan kegiatan pembongkaran (unloading) termasuk tindakan korektif 2 yang tidak berpengaruh nyata terhadap sistem muskuloskeletal. Selain itu, analisis gaya tekan dilakukan hanya untuk aktivitas pembebanan terhadap gaya tekan total yang bekerja pada L5/ S1. Gaya tekan untuk aktivitas pembebanan adalah 7.186,22 Newton atau lebih dari dua kali lipat dari batas aman maksimum 3.400 Newton. Perbaikan dilakukan dengan menggunakan metode QFD. Sebagai solusinya adalah dibuat troli. Troli tersebut mampu mereduksi gaya tekan total pada aktivitas pembebanan menjadi 3.180,52 Newton dan berhasil mengubah menjadi kategori tindakan korektif 1.
\end{abstract}

Kata kunci: biomekanik; gangguan muskuloskeletal; Sistem Analisis Postur Kerja Ovako; OWAS; Quality Function Deployment; QFD

\begin{abstract}
[REDUCTION OF MUSCULOSCELETAL DISORDERS RISK ON LASER PERFORATOR MACHINES AREA IN CIGARETTE COMPANIES USING QFD AND OWAS] Inside this cigarette production company, there is a laser perforator machine. After the installation of the laser perforator machine 50, problems related to musculoskeletal disorders arise. During the interview, the operator complained about low back pain due to manual handling of the material. After analyzing the OWAS method on two loading and unloading activities, problems were found related to musculoskeletal disorders. It was found that the loading activity was categorized as 3 meaning that posture had a very detrimental effect on the musculoskeletal system. Meanwhile, unloading activities included category 2 which had no significant effect on the musculoskeletal system. In addition, the biomechanical analysis was carried out only for the loading activity against the total compressive force acting on L5 / S1. The compressive force for loading activity is 7,186.22 Newton or more than twice the maximum safe limit of 3,400 Newton. Repairs were made using the QFD method. The solution is to make the moving trolley. The moving trolley is able to reduce the total compressive force on the loading activity to 3,180.52 Newton and also, reduce the level to category 1.
\end{abstract}

Keywords: biomechanics; musculoskeletal disorders; Ovako Working Posture Analysis System; OWAS; Quality Function Deployment; QFD; Trolley

1. Pendahuluan

Banyak industri menghadapi tantangan besar

*Penulis Korespondensi.

E-mail: hery.azwir@president.ac.id dalam kompetisi global sehingga harus terus meningkatkan strategi rantai pasokan agar berhasil bertahan dan tumbuh. Salah satu aspek terpenting dari rantai pasokan adalah memastikan operasi produksi yang optimal. PT XYZ yang merupakan salah satu perusahaan rokok terkemuka di Indonesia yang 
memproduksi berbagai macam merek rokok dunia, memutuskan untuk mengadopsi teknologi baru yaitu mesin laser perforator 50 untuk mengurangi kandungan tar dan nikotin di dalam rokok. Penanganan material pada mesin laser perforator 50 ini saat melakukan aktivitas muat-bongkar (loading-unloading) dilakukan secara manual oleh operator. Bobot material yang harus ditangani bervariasi dari 27 hingga $29 \mathrm{~kg}$ gelendong (bobbin) kertas jumbo. Selama shift delapan jam, sekitar 45 gelendong kertas dimuat dan dibongkar oleh dua operator. Secara keseluruhan ada enam operator melakuan tugas ini secara bergantian. Sayangnya dengan kondisi pekerjaan tersebut, operator memiliki keluhan terkait nyeri pinggang.

Ergonomi adalah upaya ilmu pengetahuan, teknologi, dan seni untuk merancang alat, mesin, sistem, organisasi, dan lingkungan yang menyesuaikan dengan kemampuan dan keterbatasan manusia untuk mencapai kondisi yang sehat, aman, nyaman, produktif, serta efisien dengan memaksimalkan dan mengoptimalkan penggunaan tubuh manusia (Christy, 2019). Operator dalam melakukan aktifitas di stasiun kerja (workstation) dapat mengalami gangguan muskuloskeletal yang terjadi akibat paparan pekerjaan yang terus berulang pada frekuensi tinggi atau rendah, dan adanya beban dalam jangka panjang. Gejalanya dapat bermacammacam seperti rasa tidak nyaman dan sakit (Berlin et al., 2017). Biomekanika merupakan satu dari empat bidang penelitian tentang ergonomi. Penelitian tentang kekuatan fisik manusia yang meliputi kekuatan fisik manusia saat bekerja dan bagaimana peralatan harus didesain agar sesuai dengan kemampuan fisik manusia saat melakukan aktivitas pekerjaan tersebut (Theopilus et al., 2018) and (Berlin et al., 2017).

Tempat kerja atau desain pekerjaan yang buruk sering kali menyebabkan penanganan material dilakukan secara manual. Seperempat cedera atau kecelakaan di wilayah kerja terjadi dengan metode penanganan yang dilakukan secara manual (Theopilus et al., 2018). Produktivitas dan kesehatan pekerja di tempat kerja dapat ditingkatkan dengan intervensi ergonomi (Shorrock \& Williams, 2016). Namun, bekerja di tempat kerja yang tidak tepat dapat menyebabkan berkembangnya berbagai jenis gangguan muskuloskeletal di antara para pekerja. Penyakit akibat kerja, cedera akibat stres yang berulang, dan sindrom kelelahan akibat kerja merupakan masalah yang sebagian besar mempengaruhi lengan dan punggung pekerja (Maurice et al., 2019).

Kelelahan tubuh di tempat kerja sering kali menyebabkan cedera stres berulang dan gangguan muskuloskeletal terkait pekerjaan (Sokhibi \& Primadasa, 2019). Gerakan repetitif yang tinggi yang tidak didukung oleh kondisi ergonomis dapat mengakibatkan operator mengalami gangguan muskuloskeletal. Banyak penelitian telah dilakukan terkait dengan gangguan muskuloskeletal, di antaranya workstation game computer (Yassierli et al., 2018) yang meneliti pengaruh stasiun kerja ergonomis dan non ergonomis terhadap kelelahan yang dialami oleh gamers, desain alat untuk meminimalkan beban kerja operator dalam penanganan material (Theopilus et al., 2018) menggunakan NIOSH, RULA, dan NASA-TLX, desain troli untuk penanganan beras (Sokhibi et al., 2018) dengan menggunakan REBA dan NORDIC Questioner, desain dan pengembangan shower tempat tidur (Fitriani \& Purnomo, 2018) menggunakan QFD. Dari sejumlah penelitian tersebut dapat dilihat bahwa pencarian solusi terhadap gangguan muskuloskeletal pendekatannya berbeda-beda dan sangat bergantung pada kasusnya.

Beberapa metode untuk mengatasi masalah ini tersedia, di antaranya dengan Nordic Body Map (Sokhibi \& Primadasa, 2019), Rapid Entire Body Assessment and Washington State Checklist (Kosasih et al., 2019), Rapid Upper Limb Assessment (Wahyuniardi \& Reyhanandar, 2018), National Institute for Occupational and Health juga NASA-TLX (Theopilus et al., 2018), Quick Exposure Check (Sari et al., 2017), Human Error Assessment and Reduction Technique (Safitri et al., 2017), analisis dan desain ergonomis makro (Haripurna \& Purnomo, 2017) dan Ovako Work Posture Analysis System atau OWAS (Bintang \& Dewi, 2017) (GóMez-GaláN et al., 2017).

Kasus yang dihadapi dalam penelitian ini, setelah dilakukan wawancara dengan beberapa operator dari tiga shift berbeda mengenai kondisi kerja, ditemukan adanya keluhan fisik terkait gangguan punggung bawah (low back disorders). Ada dua tujuan dari penelitian ini. Pertama, untuk mengidentifikasi gangguan muskuloskeletal yang dihadapi oleh operator di area mesin laser perforator. Kedua, mengurangi gangguan muskuloskeletal yang dihadapi oleh operator yang bekerja di area mesin laser perforator. Metode OWAS adalah salah satu metode yang paling banyak digunakan dan direkomendasikan dalam berbagai studi untuk mengevaluasi postur pembebanan pekerja (GóMezGaláN et al., 2017) selain itu, metode ini masuk kategori semi-direct yang tidak mewajibkan penggunaan perangkat elektronik untuk pengukuran yang dipasangkan pada tubuh operator namun dapat dibantu dengan software yang dalam penelitian ini menggunakan Ergo Fellow. Selain OWAS, analisis gaya tekan akan diterapkan dalam kasus ini. Setelah dilakukan analisis cukup mendalam maka dengan bantuan QFD dibuatlah alat bantu material handling.

\section{Metodologi Penelitian}

Sebelum melakukan pengumpulan data, dilakukan observasi tentang kondisi tempat kerja dan cara operator menangani material. Kondisi tempat kerja saat itu dan metode penanganan material dipelajari untuk menentukan masalah utama dan jenis data yang diperlukan untuk analisis. Setelah mengetahui permasalahannya, maka dilakukan perekaman video untuk postur kerja Ovako. Hasil analisis tersebut akan digunakan sebagai data pendukung bahwa kondisi saat itu memerlukan perbaikan terutama pada peralatan material handling. Massa benda dan operator, panjang bagian tubuh operator, dan sudut postur diambil untuk 
Tabel 1. Klasifikasi dan Kode Postur Tubuh di OWAS

\begin{tabular}{clc}
\hline \multicolumn{1}{c}{ Body } & \multicolumn{1}{c}{ Working Posture } & Code \\
\hline \multirow{4}{*}{ Punggung } & 1 \\
& Lurus & 2 \\
& Menekuk & 3 \\
& Memutar & 4 \\
\hline \multirow{3}{*}{ Lengan } & Kenekuk dan memutar & 1 \\
& Sedua lengan di bawah bahu lengan setinggi atau di atas bahu & 2 \\
& Kedua lengan setinggi atau di atas bahu & 3 \\
\hline \multirow{5}{*}{ Kaki } & Duduk & 1 \\
& Berdiri dengan menggunakan dua kaki lurus & 2 \\
& Berdiri dengan menggunakan satu kaki lurus & 3 \\
& Berdiri atau jongkok dengan menggunakan dua kaki yang ditekuk & 4 \\
& Berdiri atau jongkok dengan menggunakan satu kaki ditekuk & 5 \\
& Berlutut & 6 \\
& Berjalan & 7 \\
\hline \multirow{3}{*}{ Beban } & Kurang atau sama dengan 10 kg & 1 \\
& Lebih dari 10 kg dan kurang atau sama dengan 20 kg & 2 \\
& Lebih dari 20 kg & 3 \\
\hline
\end{tabular}

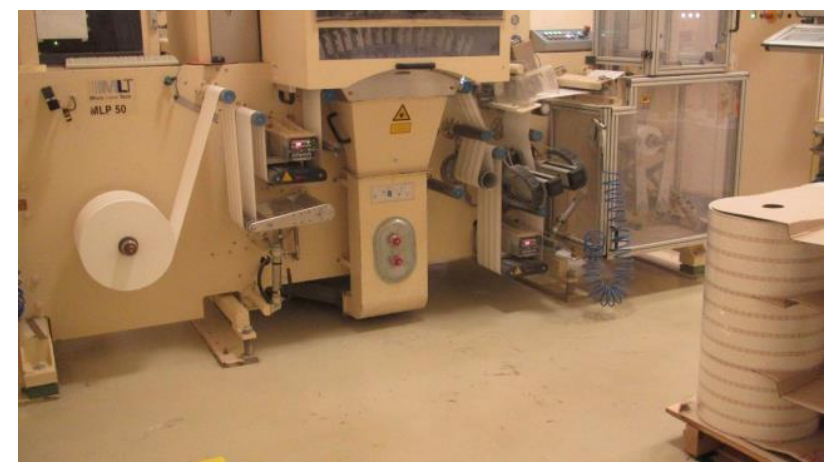

Gambar 1. Area Mesin Laser Perforator

diidentifikasi dalam analisis gaya tekan untuk mengetahui gaya tekan total yang bekerja pada L5/ S1. Setelah mendapatkan data dan melakukan analisis gaya tekan, perbaikan terhadap masalah ergonomi dapat diusulkan dengan menggunakan quality function deployment (QFD). Hasil perbaikan akan dianalisis dan dibandingkan dengan kondisi sebelumnya.

$$
\text { Ovako Working Posture Analysis System }
$$
(OWAS) adalah metode yang digunakan untuk mengidentifikasi komplikasi pada muskuloskeletal yang menyebabkan nyeri pada tubuh manusia. Postur tubuh yang diidentifikasi dalam analisis postur kerja Ovako adalah punggung (4 postur), lengan (3 postur), tungkai (7 postur), dan gaya total (3 kategori) (Bintang \& Dewi, 2017), sebagaimana dijelaskan dalam Tabel 1 (Lee \& Han, 2013).

Hasil analisis postur kerja OWAS dibagi menjadi empat level kategori tindakan. Setiap kategori tindakan memiliki interpretasi terkait dengan gangguan muskuloskeletal:

- Kategori 1 berarti postur tubuh dalam keadaan normal dan tidak memberikan pengaruh yang merugikan terutama pada sistem muskuloskeletal. Akibatnya, tidak perlu tindakan korektif.

- Kategori 2 berarti postur tubuh sedang menghadapi beberapa masalah dan memberikan pengaruh yang merugikan bagi sistem muskuloskeletal, namun tidak signifikan. Alhasil, memang perlu tindakan korektif secepatnya.

- Kategori 3 berarti postur tubuh memiliki efek berbahaya yang signifikan pada sistem muskuloskeletal. Alhasil, tindakan korektif segera dilakukan.

- Kategori 4 berarti postur tubuh merupakan kondisi ekstrim dan berbahaya bagi sistem muskuloskeletal. Akibatnya tindakan korektif untuk perbaikan harus segera dilakukan.

Dalam melakukan analisis postur kerja Ovako terdapat prosedur sederhana yang harus diikuti: (1) Memilih aktivitas/ postur kerja yang akan dianalisis. (2) Menganalisis setiap bagian tubuh yang menjadi perhatian OWAS; punggung, lengan, kaki dan kekuatan. (3) Mengidentifikasi dan menyandikan setiap postur kerja, misalnya: punggung operator sedang membungkuk ke depan dalam mengangkat material. (4) Kombinasi dasar OWAS diidentifikasi untuk mengetahui kategori tindakan korektif apa yang harus dilakukan.

\section{Hasil dan Pembahasan}

Pada area laser, Gambar 1, terdapat dua mesin laser perforator 50 yang masing-masing mesin dioperasikan oleh dua operator. Mesin ini sangat sensitif terhadap getaran dan suhu. Karena itu, untuk 


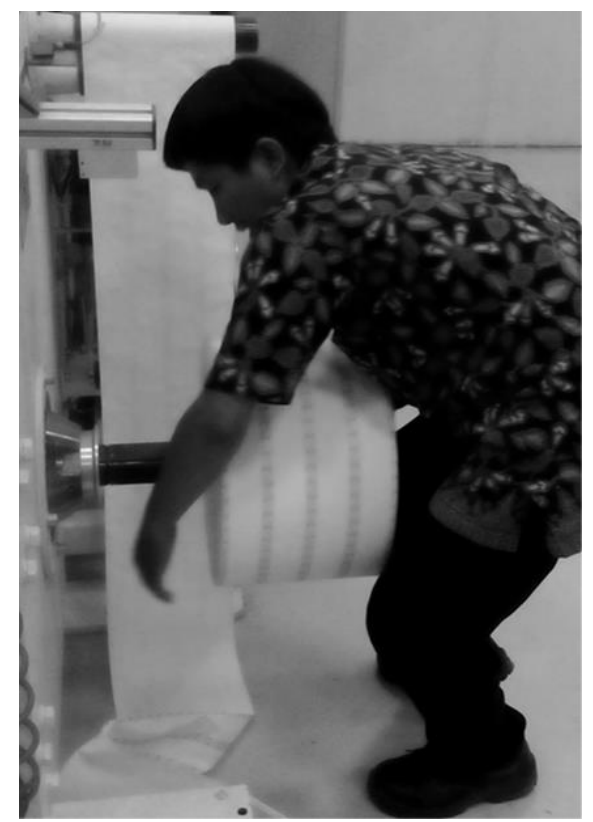

Gambar 2. Metode Kerja Non-Ergonomis di Area Mesin Laser Perforator

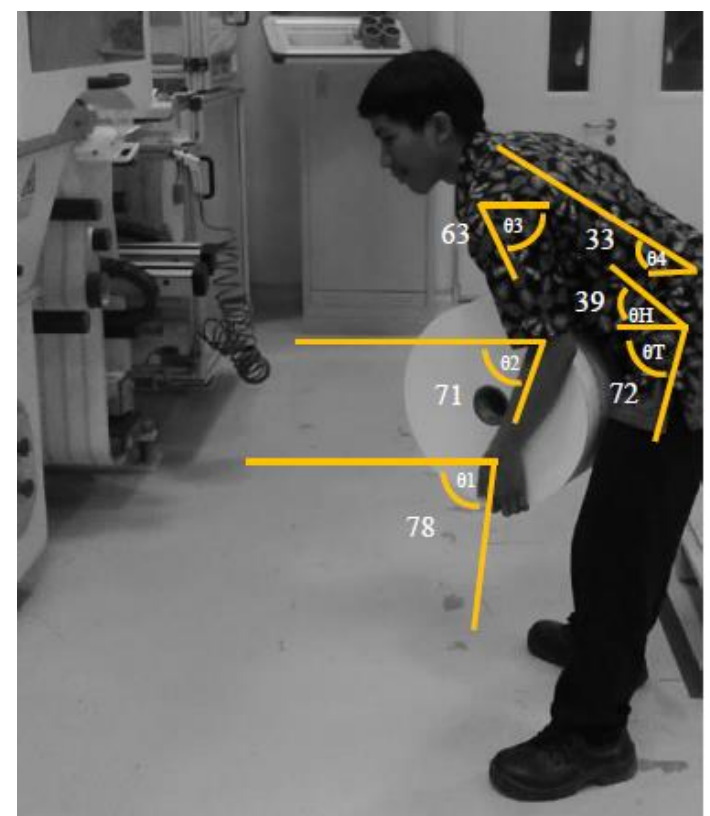

Gambar 3. Postur Operator Bekerja Saat Aktivitas Memuat

Tabel 1. Hasil Frame Video

\begin{tabular}{ccc}
\hline Operator & Aktivitas Muat (Loading) & Aktivitas Bongkar (Unloading) \\
\hline Frame 1 & Kategori 3 & Kategori 2 \\
Frame 2 & Kategori 3 & Kategori 2 \\
Frame 3 & Kategori 3 & Kategori 2 \\
Frame 4 & Kategori 3 & Kategori 3 \\
Frame 5 & Kategori 3 & Kategori 2 \\
Frame 6 & Kategori 3 & Kategori 2 \\
\hline
\end{tabular}

memastikan mesin bekerja maksimal tanpa gangguan dari masalah temperatur, ruangan disetel pada temperatur yang sejuk. Selanjutnya untuk mengatasi getaran, mesin dipasang di lantai. Namun masalah muncul saat operator memuat material ke mesin. Operator tidak dapat bekerja dalam kondisi normal karena kondisi ini.

Ketinggian unwinder shaft yang tidak tepat pada mesin menimbulkan masalah ergonomis yaitu gangguan muskuloskeletal seperti nyeri punggung karena operator membungkukkan badan ke depan saat menangani material. Selain itu, operator juga tidak diberikan peralatan pendukung untuk penanganan material dalam mengangkat dan memposisikan material pada mesin laser perforator 50

Gambar 2 menunjukkan aktivitas khas (memuat gelendong kertas) di area mesin. Kegiatan ini direkam di lantai produksi dan kemudian dianalisis di kantor. Untuk setiap aktivitas hanya diamati satu operator dari shift 1 (06:00 - 14:00) karena aktivitas muat dan bongkar yang dilakukan lebih kurang sama. Durasi pengamatan selama 30 detik, setiap 5 detik diambil sampel dan didapatkan 6 frame video. Pengambilan sampling dilakukan dengan teknik purposive sampling yang termasuk pada kategori non-probability sampling. Jumlah frame rekaman video yang dianalisis dalam penelitian ini adalah 12 (2 aktivitas x 6 frame).
Tabel 1 menunjukkan hasil frame rekaman video dari masing-masing kegiatan. Dari dua aktivitas yang diamati, yaitu kegiatan muat-bongkar material, ditemukan bahwa kegiatan muat masuk kategori 3, sedangkan kegiatan bongkar masuk pada kategori 2 . Dari hasil OWAS, hanya kegiatan muat yang akan dianalisis selanjutnya menggunakan analisis gaya tekan.

\section{Analisis gaya tekan}

Dalam menghitung gaya tekan pada L5 / S1, diperlukan enam tahapan untuk menghitung gaya tekan total. Gambar 3 menunjukkan postur operator saat memuat material dan sudut postur diidentifikasi untuk perhitungan. Analisis gaya tekan merujuk pada Occupational Biomechanics (Chaffin et al., 2006) termasuk penentuan prosentase massa tubuh. Tabel 2 merangkum sudut postur operator.

\section{Kekuatan resultan di telapak tangan}

Pertama, dalam menghitung gaya tekan total, resultan gaya telapak tangan dihitung. Massa telapak tangan sama dengan $0,6 \%$ dari total massa manusia. Tabel 3 menunjukkan data yang diperlukan untuk perhitungan resultan gaya telapak tangan dan Tabel 4 merupakan ringkasan hasil gaya telapak tangan.

$$
\text { Bobot telapak tangan }(W p)=0,6 \% \times \text { Mope } \times g
$$$$
=0,006 \times 70 \text { kilogram } \times 9,8 \mathrm{~m} / \mathrm{s} 2
$$ 
Tabel 2. Sudut Postur Operator

\begin{tabular}{lcc}
\hline \multicolumn{1}{c}{ Postur Tubuh } & Simbol & Sudut $\left(^{\circ}\right)$ \\
\hline Sudut telapak tangan & $\theta 1$ & 78 \\
Sudut lengan bawah & $\theta 2$ & 71 \\
Sudut lengan atas & $\theta 3$ & 63 \\
Sudut punggung & $\theta 4$ & 33 \\
Sudut perut & $\theta \mathrm{H}$ & 39 \\
Sudut kaki & $\theta \mathrm{T}$ & 72 \\
\hline
\end{tabular}

Tabel 3. Data untuk Menghitung Hasil Gaya Telapak Tangan

\begin{tabular}{lll}
\hline Data & Nilai & Simbol \\
\hline Massa operator & $70 \mathrm{~kg}$ & $\mathrm{M}_{\mathrm{ope}}$ \\
Massa objek & $28 \mathrm{~kg}$ & $\mathrm{M}_{\mathrm{obj}}$ \\
Akselerasi gravitasi & $9,8 \mathrm{~m} / \mathrm{s}^{2}$ & $\mathrm{~g}$ \\
Persentase massa telapak tangan & $0,6 \%$ & \\
Panjang telapak tangan & 0,18 meter & $\mathrm{SL} 1$ \\
Sudut telapak tangan & $78^{\circ}$ & $\theta 1$ \\
\hline
\end{tabular}

Tabel 4. Hasil Gaya Resultan di Telapak Tangan

\begin{tabular}{ll}
\hline Kategori & Hasil perhitungan \\
\hline Resultan gaya Y-axis di telapak tangan & 141,32 Newton \\
Momen di telapak tangan & 5,34 Newton \\
\hline
\end{tabular}

Tabel 5. Data untuk Menghitung Hasil Angkatan Lengan Bawah

\begin{tabular}{lll}
\hline Data & Nilai & Simbol \\
\hline Massa operator & $70 \mathrm{~kg}$ & $\mathrm{M}_{\text {ope }}$ \\
Massa objek & $28 \mathrm{~kg}$ & $\mathrm{M}_{\mathrm{obj}}$ \\
Akselerasi gravitasi & $9,8 \mathrm{~m} / \mathrm{s}^{2}$ & $\mathrm{~g}$ \\
Persentase massa lengan bawah & $1,7 \%$ & \\
Panjang lengan bawah & $0,28 \mathrm{~meter}$ & $\mathrm{SL} 2$ \\
Sudut lengan bawah & $71^{\circ}$ & $\theta 2$ \\
Centre of mass distance proportion to elbow & $43 \%$ & $\lambda 2$ \\
Resultan gaya Y-axis di telapak tangan & 141,32 & Fyw \\
Momen di telapak tangan & 5,34 & Mw \\
\hline
\end{tabular}

Tabel 6. Hasil Gaya Resultan di Lengan Bawah

\begin{tabular}{ll}
\hline Kategori & Hasil perhitungan \\
\hline Resultan gaya Y-axis pada lengan bawah & 152,98 Newton \\
Momen di lengan bawah & 18,45 Newton \\
\hline
\end{tabular}

$$
=4,12 \text { Newton }
$$

$$
\begin{gathered}
\text { Berat benda }=\text { Mobj } \times \mathrm{g} \\
=28 \text { kilogram } \times 9,8 \mathrm{~m} / \mathrm{s} 2 \\
=274,4 \text { Newton }
\end{gathered}
$$

Resultan gaya sumbu $Y$ pada telapak tangan (Fyw)

$$
=\text { Mobj } x \mathrm{~g} / 2+W p
$$$$
=28 \text { kilogram } x 9,8 \mathrm{~m} / \mathrm{s} 2 / 2+4,12 \text { Newton }
$$

$$
=141,32 \text { Newton }
$$

$$
\begin{gathered}
\text { Momen di telapak tangan }(M w) \\
=\text { Fyw } x \text { SL } 1 \times \operatorname{Cos} \theta 1 \\
=141,32 \text { Newton } x 0,18 \text { Meter } x \cos 78 \\
=5,34 \text { Newton }
\end{gathered}
$$

\section{Gaya resultan di lengan bawah}

Langkah kedua dalam menghitung gaya tekan pada L5/ S1 adalah menentukan resultan gaya pada lengan bawah. Tabel 5 menunjukkan data yang diperlukan untuk perhitungan resultan gaya lengan bawah. Dengan menggunakan perhitungan yang sama seperti sebelumnya maka akan didapatkan hasil sebagaimana ditampilkan pada Tabel 6.

\section{Gaya yang dihasilkan di lengan atas}

Langkah ketiga adalah menghitung lengan atas. Massa lengan atas adalah 2,8\% dari total massa manusia. Tabel 7 menunjukkan data yang diperlukan untuk menghitung resultan gaya lengan atas. Dengan menggunakan perhitungan yang sama seperti sebelumnya maka akan didapatkan hasil sebagaimana ditampilkan pada Tabel 8.

\section{Gaya resultan di punggung}

Langkah keempat adalah menentukan resultan gaya pada punggung. Persentase massa punggung adalah $50 \%$ dari total massa manusia. Tabel 9 
Tabel 7. Data untuk Menghitung Resultant Gaya Lengan Atas

\begin{tabular}{lll}
\hline \multicolumn{1}{c}{ Data } & \multicolumn{1}{c}{ Nilai } & Simbol \\
\hline Massa operator & $70 \mathrm{~kg}$ & $\mathrm{M}_{\mathrm{ope}}$ \\
Massa objek & $28 \mathrm{~kg}$ & $\mathrm{M}_{\mathrm{obj}}$ \\
Akselerasi gravitasi & $9,8 \mathrm{~m} / \mathrm{s}^{2}$ & $\mathrm{~g}$ \\
Persentase massa lengan atas & $2,8 \%$ & \\
Panjang lengan atas & $0,28 \mathrm{~meter}$ & $\mathrm{SL} 3$ \\
Sudut lengan atas & $63^{\circ}$ & $\theta 3$ \\
Centre of mass distance proportion to the shoulder & $43,6 \%$ & $\lambda 3$ \\
Resultan gaya Y-axis pada lengan atas & 152,98 & $\mathrm{Fye}$ \\
Momen di lengan atas & 18,45 & $\mathrm{Me}$ \\
\hline
\end{tabular}

Tabel 8. Hasil Gaya Resultan di Lengan Atas

\begin{tabular}{lc}
\hline \multicolumn{1}{c}{ Kategori } & Hasil Perhitungan (Newton) \\
\hline Resultan gaya Y-axis pada lengan atas & 172,19 \\
Momen di lengan atas & 38,06 \\
\hline
\end{tabular}

Tabel 9. Data untuk Menghitung Resultan Gaya Punggung

\begin{tabular}{lll}
\hline \multicolumn{1}{c}{ Data } & \multicolumn{1}{c}{ Nilai } & Simbol \\
\hline Massa operator & $70 \mathrm{~kg}$ & $\mathrm{M}_{\mathrm{ope}}$ \\
Massa objek & $28 \mathrm{~kg}$ & $\mathrm{M}_{\mathrm{obj}}$ \\
Akselerasi gravitasi & $9,8 \mathrm{~m} / \mathrm{s}^{2}$ & $\mathrm{~g}$ \\
Persentase massa punggung & $50 \%$ & \\
Panjang punggung & 0,55 meter & $\mathrm{SL} 4$ \\
Sudut punggung & $33^{\circ}$ & $\theta 4$ \\
Centre of mass distance proportion to L5/S1 & $67 \%$ & $\lambda 4$ \\
Resultan gaya Y-axis pada punggung & 172,19 & $\mathrm{Fys}$ \\
Momen di punggung & 38,06 & $\mathrm{Ms}$ \\
\hline
\end{tabular}

Tabel 10. Hasil Gaya Resultan di Punggung

\begin{tabular}{lc}
\hline \multicolumn{1}{c}{ Kategori } & Hasil Perhitungan \\
\hline Resultan gaya Y-axis pada punggung & 687,38 Newton \\
Momen punggung & 341,39 Newton \\
\hline
\end{tabular}

Tabel 11. Data untuk Resultan Gaya Erektor Tulang Belakang

\begin{tabular}{|c|c|c|}
\hline Data & Nilai & Simbol \\
\hline Sudut perut & 72 & $\theta \mathrm{H}$ \\
\hline Sudut kaki & 39 & $\theta \mathrm{T}$ \\
\hline Momen punggung & 341,39 & Mt \\
\hline Area diafragma perut & 0,0465 & AA \\
\hline Panjang otot erektor tulang belakang dari L5/ S1 & 0,05 meter & $\mathrm{E}$ \\
\hline Jarak antara otot perut ke L5/ S1 & 0,11 & $\mathrm{D}$ \\
\hline
\end{tabular}

Tabel 12. Hasil Resultan Gaya di Erektor Tulang Belakang

\begin{tabular}{ll}
\hline \multicolumn{1}{c}{ Kategori } & \multicolumn{1}{c}{ Hasil Perhitungan } \\
\hline Tekanan perut & 1471,17 Newton \\
Kekuatan perut & 68,41 Newton \\
Kekuatan otot & 6677,23 Newton \\
\hline
\end{tabular}

menunjukkan data yang diperlukan untuk perhitungan resultan gaya punggung. Dengan menggunakan perhitungan yang sama seperti sebelumnya maka akan didapatkan hasil sebagaimana ditampilkan pada Tabel 10.

\section{Gaya resultan erektor tulang belakang}

Langkah selanjutnya adalah menghitung gaya pada erektor tulang belakang. Data yang dibutuhkan untuk penghitungan ditunjukkan pada Tabel 11 . Dengan menggunakan perhitungan yang sama seperti sebelumnya maka akan didapatkan hasil sebagaimana ditampilkan pada Tabel 12.

\section{Gaya kompresi total}

Langkah terakhir adalah mengukur gaya tekan pada L5/ S1. Data yang diperlukan untuk penghitungan pada langkah ini dapat dilihat pada Tabel 13. 
Tabel 13. Data untuk Menghitung Gaya Kompresi Total

\begin{tabular}{lll}
\hline \multicolumn{1}{c}{ Data } & \multicolumn{1}{c}{ Nilai } & \multicolumn{1}{c}{ Simbol } \\
\hline Bobot benda & 274,4 Newton & $\mathrm{W}_{\text {obj }}$ \\
Bobot telapak tangan & 4,12 Newton & $\mathrm{Wp}$ \\
Bobot lengan bawah & 11,66 Newton & Wla \\
Bobot lengan atas & 19,21 Newton & Wua \\
Bobot punggung & 343 Newton & Wt \\
Kekuatan perut & 68,41 Newton & FA \\
Kekuatan otot pada erektor tulang belakang & 6677,23 Newton & FM \\
\hline
\end{tabular}

Tabel 14. Relasi Antara Kebutuhan Operator dan Spesifikasi Teknis

\begin{tabular}{|c|c|c|}
\hline No & Kebutuhan Operator & Spesifikasi Teknis Produk \\
\hline 1 & Easy to use (mudah digunakan) & Simple design of product: mobile trolley \\
\hline 2 & Easy to move (mudah dipindahkan) & The product has wheels (memiliki roda) \\
\hline 3 & Easy to adjust (mudah disesuaikan) & Having adjustable bolt (ada baut bisa diatur) \\
\hline 4 & $\begin{array}{l}\text { Can load heavy material without } \\
\text { distraction (mudah memuat material } \\
\text { berat) }\end{array}$ & $\begin{array}{l}\text { The wheels have break (ada penahan roda) } \\
\text { The product is constructed from light steel plate } \\
\text { (menggunakan material baja ringan) }\end{array}$ \\
\hline
\end{tabular}

$$
\begin{gathered}
\text { Bobot total }(\text { Wtot }=\text { Wobj }+2 W p+2 W l a+ \\
2 W u a+W t \\
=274,4+2(4,12)+2(11,66)+2(19,21)+343 \\
=687,37 \text { Newton }
\end{gathered}
$$

$$
\begin{aligned}
& \text { Gaya tekan }=\text { Wtot } x \cos \theta 4-F A+F M \\
& \begin{aligned}
=686,98 & \text { Newton } x \cos 33-259,95 \\
& +6458,31 \text { Newton } \\
& =7186,22 \text { Newton }
\end{aligned}
\end{aligned}
$$

Analisis gaya tekan pada L5/ S1 menunjukkan bahwa gaya tekan operator pada L5/ S1 melebihi batas aman kerja. Gaya tekan pada kondisi terburuk aktivitas pembebanan sebesar 7186,22 Newton atau lebih dari dua kali lipat dari batas aman kerja yaitu 3400 Newton. Maka, perbaikan perlu dilakukan untuk mengurangi masalah gangguan muskuloskeletal terkait peralatan pendukung penanganan material.

\section{Perbaikan yang diusulkan}

Hasil analisis menunjukkan bahwa tubuh yang ditekuk adalah postur paling kritis yang harus dihilangkan atau dikurangi untuk operator area laser mesin. Pengamatan lapangan menunjukkan bahwa beberapa postur kerja yang buruk dapat dikurangi secara substansial dengan bantuan peralatan bantu penanganan material. Untuk merancang peralatan penanganan material, diterapkan metode Quality Function Deployment (QFD).

QFD digunakan untuk memenuhi kebutuhan operator dengan spesifikasi peralatan material handling. Ada sejumlah langkah untuk membangun relasi antara kebutuhan dan spesifikasi tersebut dimulai dengan membuat daftar kebutuhan operator akan peralatan penanganan material baru untuk mengurangi gangguan muskuloskeletal. Untuk itu, enam operator di area laser mesin diwawancarai.
Sebagai langkah pertama adalah dari sisi keinginan operator, mereka menginginkan alat bantu yang dirancang (1) mudah digunakan, (2) mudah dipindahkan, (3) mudah diatur atau disesuaikan ketinggiannya, dan (4) dapat memuat material berat tanpa kesulitan. Selanjutnya langkah kedua berdasarkan keinginan tersebut maka spesifikasi teknis yang muncul adalah: (1) troli sederhana, (2) memiliki roda, (3) memiliki baut yang dapat diatur, (4) ada penahan roda agar tidak bergerak, (5) menggunakan material baja ringan. Berikutnya langkah ketiga yaitu menggambarkan secara lebih jelas bagaimana relasi antara kebutuhan dan harapan operator dengan spesifikasi teknis untuk merealisasikan alat bantu material handling lebih jelasnya diperlihatkan dalam Tabel 14.

Kekuatan relasi diperlihatkan dalam Gambar 4 dimana nilai 3 menunjukkan hubungan yang kuat dan 0 menandakan tidak adanya hubungan. Langkah keempat adalah menilai relasi antara spesifikasi teknis dimana (++) menyatakan hubungan positif yang sangat kuat dan (--) menyatakan hubungan yang sangat tidak kuat. Langkah kelima adalah melakukan penilaian berdasarkan skala 1 s.d. 10 terhadap kebutuhan operator tersebut berdasarkan tingkat kepentingannya (degree of importance), kondisi material handling sekarang, usulan material handling dan terakhir adalah improvement level. Penilaian improvement level berdasarkan nilai usulan perbaikan dibagi kondisi sekarang.

Langkah keenam adalah menentukan prioritas spesifikasi teknis dengan cara pembobotan. Nilai pembobotan bergantung pada seberapa kuat relasi antara kebutuhan operator dan spesifikasi teknis yang diusulkan. Semakin besar bobotnya menandakan tingkat prioritas yang makin tinggi. Sebagai contoh, importance weight untuk desain troli adalah

$$
39.82(3)+17.7(2)=154.86
$$




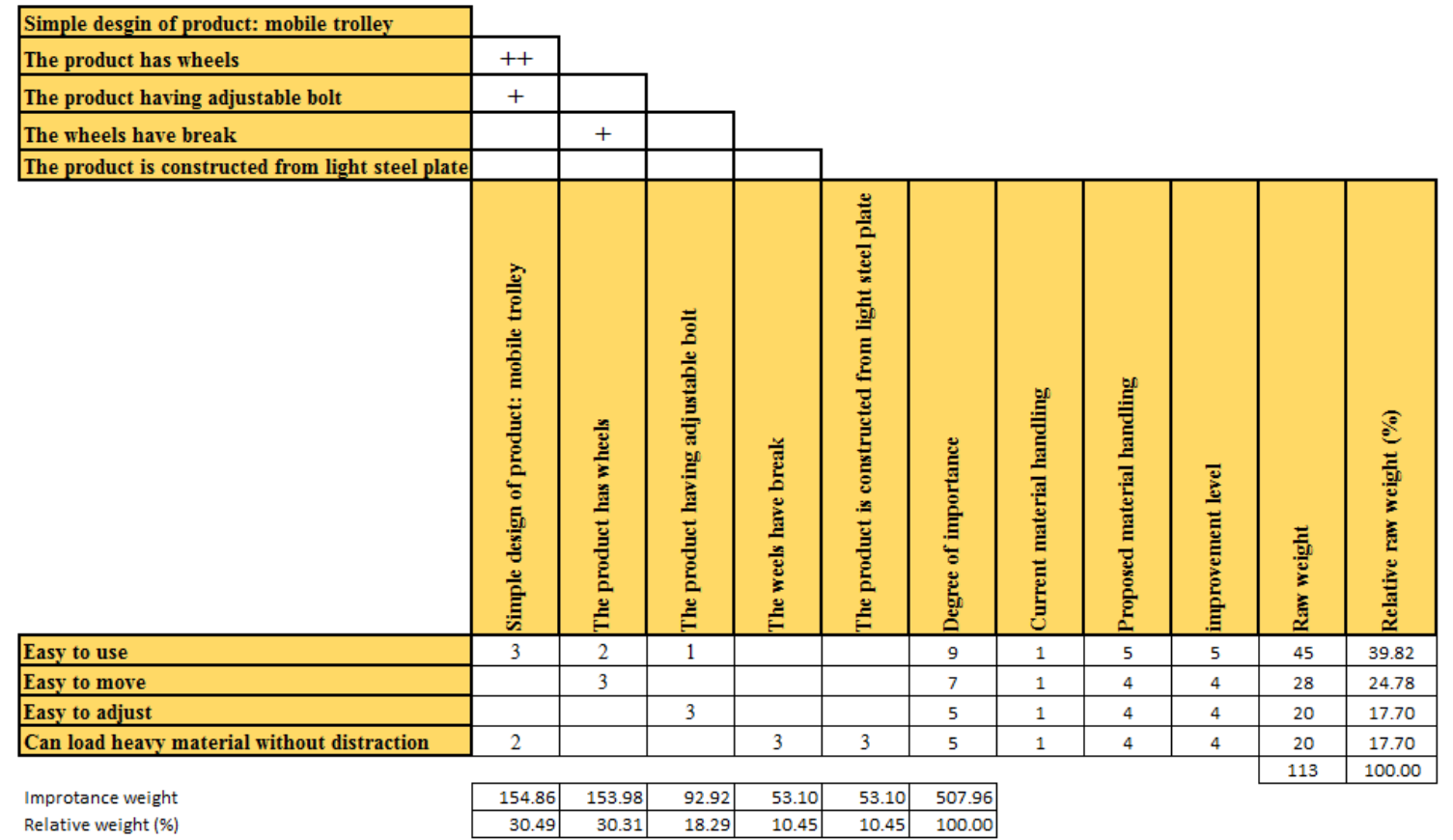

Gambar 4. House of Quality untuk Material Handling Equipment

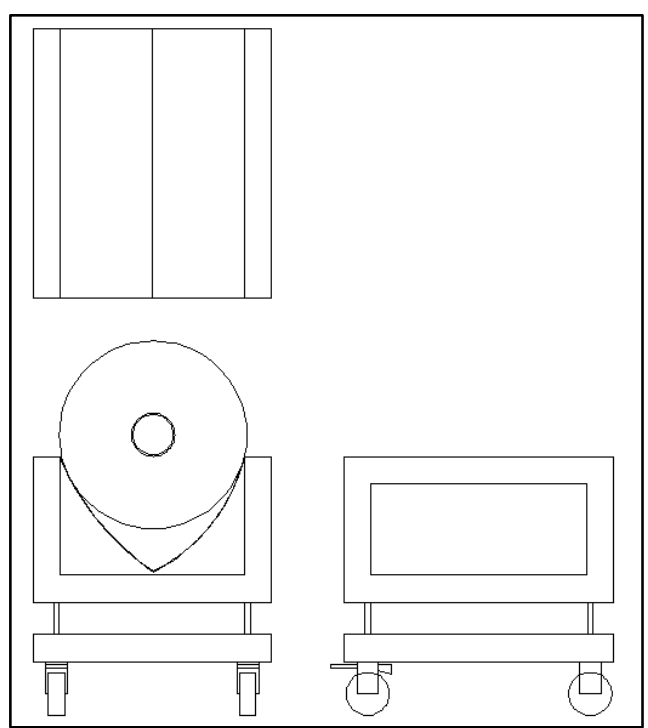

Gambar 5. Sketsa Troli dari Tiga Sudut Pandang

Untuk hasil lengkap prioritas dapat dilihat dalam Gambar 4. Setelah diskusi dengan supervisor, maka spesifikasi teknis peralatan yang akan dirancang adalah sebuah troli yang memiliki desain sederhana. Troli akan membantu operator dalam memindahkan gelendongan kertas jumbo dari area palet ke dalam mesin. Selain itu, ketinggian troli harus dapat diatur dengan menggunakan baut yang dapat diatur juga agar sesuai dengan ketinggian poros pelepas (unwinder shaft) di mesin laser perforator 50 .

Gambar 5 memperlihatkan sketsa tampilan dan desain dari troli. Usulan perbaikan dengan membangun troli karena spesifikasi pada QFD mewakili 30,49\% kebutuhan operator sesuai dengan bobot kepentingannya. Karena tidak ada korelasi negatif

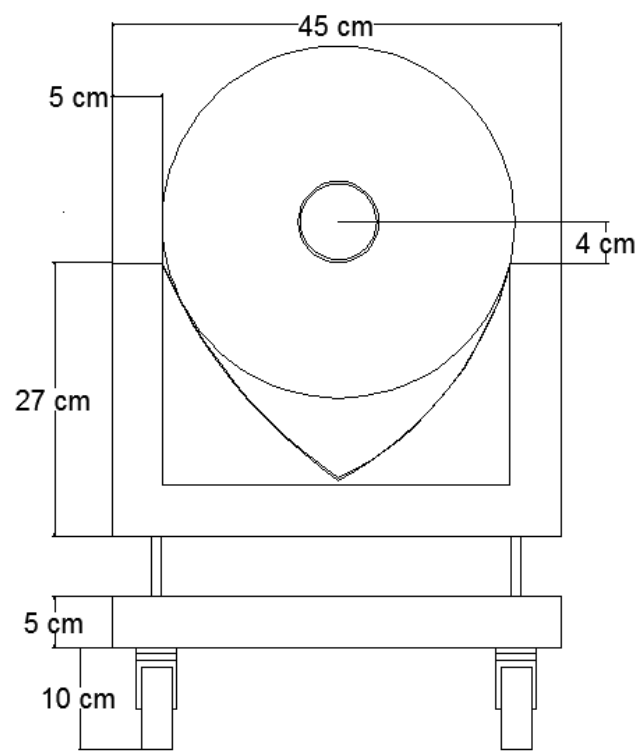

Gambar 6. Desain Troli dengan Ukuran

diantara spesifikasi produk, maka spesifikasi lainnya dapat mengikuti tanpa pertimbangan tertentu lagi.

\section{Spesifikasi produk}

Gambar 6 merupakan produk yang dikembangkan dengan menggunakan quality function deployment. Spesifikasi ukuran troli dibuat berdasarkan spesifikasi mesin laser perforator 50 karena mesin ini tidak dapat disetel. Spesifikasinya dapat dilihat pada Tabel 15

\section{Biaya peralatan penanganan material}

Troli dapat memuat hingga dua kertas gelendong jumbo. Detail perbaikan dan biaya untuk pembuatan troli ditunjukkan pada Tabel 16. 
Tabel 15. Spesifikasi Troli

\begin{tabular}{lll}
\hline No & \multicolumn{1}{c}{ Data } & Unit \\
\hline 1 & Tinggi unwinder shaft & $59 \mathrm{~cm}$ \\
2 & Lebar unwinder area & $47 \mathrm{~cm}$ \\
3 & Radius gelendong kertas & $20 \mathrm{~cm}$ \\
\hline
\end{tabular}

Tabel 16. Biaya Peralatan Penanganan Material

\begin{tabular}{|c|c|c|c|c|c|}
\hline Perbaikan & Material & & Qty & Harga/ Qty & Harga total \\
\hline Base & Light steel plate & & 1 & 350.000 & 350.000 \\
\hline Frame & Angle bar & & 1 & 225.000 & 225.000 \\
\hline Wheels & $\begin{array}{l}\text { Trolley wheels } \\
\mathrm{cm}\end{array}$ & & 4 & 75.000 & 300.000 \\
\hline Biaya total & & & & & 825.000 \\
\hline
\end{tabular}

Tabel 17. Sudut Postur Operator Setelah Perbaikan

\begin{tabular}{lcc}
\hline \multicolumn{1}{c}{ Postur Tubuh } & Simbol & Sudut $\left(^{\circ}\right)$ \\
\hline Sudut telapak tangan & $\theta 1$ & 71 \\
Sudut lengan bawah & $\theta 2$ & 47 \\
Sudut lengan atas & $\theta 3$ & 79 \\
Sudut punggung & $\theta 4$ & 83 \\
Sudut perut & $\theta \mathrm{H}$ & 85 \\
Sudut kaki & $\theta \mathrm{T}$ & 56 \\
\hline
\end{tabular}

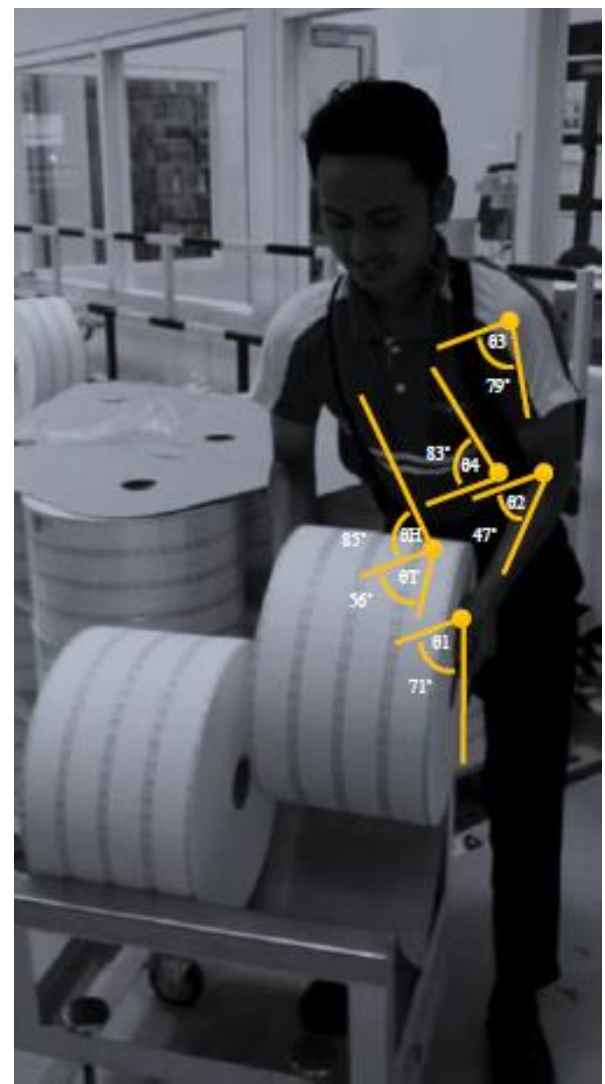

Gambar 7. Postur Operator Bekerja Setelah Perbaikan

\section{Postur tubuh sesudah perbaikan}

Setelah melakukan perbaikan maka postur operator bekerja akan terlihat sebagaimana Gambar 7 dan selanjutnya dilakukan analisis untuk mengetahui tingkat perbaikannya hasilnya diperlihatkan dalam Tabel 17.

\section{Analisis gaya tekan setelah perbaikan}

Hasil pada Tabel $\mathbf{1 8}$ menunjukkan gaya tekan total pada aktivitas pembebanan terberat setelah menggunakan troli dapat mereduksi $44,26 \%$ gaya tekan menjadi 3.180 .52 yang berada di bawah batas aman maksimum pada L5/ S1. 
Tabel 18. Data untuk Kekuatan Kompresi Total

\begin{tabular}{lll}
\hline \multicolumn{1}{c}{ Data } & \multicolumn{1}{c}{ Nilai } & \multicolumn{1}{c}{ Simbol } \\
\hline Bobot benda & 274,4 Newton & $\mathrm{W}_{\text {obj }}$ \\
Bobot telapak tangan & 4,12 Newton & $\mathrm{Wp}$ \\
Bobot lengan bawah & 11,66 Newton & Wla \\
Bobot lengan atas & 19,21 Newton & Wua \\
Bobot punggung & 343 Newton & Wt \\
Kekuatan perut & $-174,62$ Newton & FA \\
Kekuatan otot pada erektor tulang belakang & 2923,41 Newton & FM \\
\hline
\end{tabular}

Tabel 19. Analisis Sebelum-Sesudah untuk Analisis Gaya Tekan

\begin{tabular}{clc}
\hline No & Aktiftas Pemuatan & Gaya Tekanan \\
\hline $\mathbf{1}$ & Sebelum perbaikan & 7186,22 Newton \\
$\mathbf{2}$ & Setelah perbaikan & 3180,52 Newton \\
\hline
\end{tabular}

Tabel 20. Situasi Sebelum dan Setelah Perbaikan dengan Menggunakan Troli Khusus Sebelum perbaikan:

\begin{tabular}{|c|c|c|c|c|c|c|c|c|c|c|c|c|c|c|c|c|c|}
\hline \multirow[t]{2}{*}{ Operator } & \multicolumn{4}{|c|}{$\begin{array}{c}\text { Back } \\
\text { (Punggung) } \\
\end{array}$} & \multicolumn{3}{|c|}{$\begin{array}{c}\text { Arms } \\
\text { (Lengan) }\end{array}$} & \multicolumn{7}{|c|}{$\begin{array}{c}\text { Legs } \\
\text { (Kaki) }\end{array}$} & \multicolumn{3}{|c|}{$\begin{array}{c}\text { Force } \\
\text { (Beban) }\end{array}$} \\
\hline & 1 & 2 & 3 & 4 & 1 & 2 & 3 & 1 & 2 & 3 & 4 & 5 & 6 & 7 & 1 & 2 & 3 \\
\hline Frame 1 & & $\sqrt{ }$ & & & $\sqrt{ }$ & & & & $\sqrt{ }$ & & & & & & & & $\sqrt{ }$ \\
\hline Frame 2 & & $\sqrt{ }$ & & & $\sqrt{ }$ & & & & $\sqrt{ }$ & & & & & & & & $\sqrt{ }$ \\
\hline Frame 3 & & $\sqrt{ }$ & & & $\sqrt{ }$ & & & & $\sqrt{ }$ & & & & & & & & $\sqrt{ }$ \\
\hline Frame 4 & & $\sqrt{ }$ & & & $\sqrt{ }$ & & & & $\sqrt{ }$ & & & & & & & & $\sqrt{ }$ \\
\hline Frame 5 & & $\sqrt{ }$ & & & $\sqrt{ }$ & & & & & & $\sqrt{ }$ & & & & & & $\sqrt{ }$ \\
\hline Frame 6 & & $\sqrt{ }$ & & & $\sqrt{ }$ & & & & & & $\sqrt{ }$ & & & & & & $\sqrt{ }$ \\
\hline
\end{tabular}

\section{Setelah perbaikan:}

\begin{tabular}{|c|c|c|c|c|c|c|c|c|c|c|c|c|c|c|c|c|c|}
\hline \multirow[t]{2}{*}{ Operator } & \multicolumn{4}{|c|}{$\begin{array}{c}\text { Back } \\
\text { (Punggung) } \\
\end{array}$} & \multicolumn{3}{|c|}{$\begin{array}{c}\text { Arms } \\
\text { (Lengan) }\end{array}$} & \multicolumn{7}{|c|}{$\begin{array}{c}\text { Legs } \\
\text { (Kaki) }\end{array}$} & \multicolumn{3}{|c|}{$\begin{array}{c}\begin{array}{c}\text { Force } \\
\text { (Beban) }\end{array} \\
\end{array}$} \\
\hline & 1 & 2 & 3 & 4 & 1 & 2 & 3 & 1 & 2 & 3 & 4 & 5 & 6 & 7 & 1 & 2 & 3 \\
\hline Frame 1 & $\sqrt{ }$ & & & & $\sqrt{ }$ & & & & $\sqrt{ }$ & & & & & & & & $\sqrt{ }$ \\
\hline Frame 2 & $\sqrt{ }$ & & & & $\sqrt{ }$ & & & & $\sqrt{ }$ & & & & & & & & $\sqrt{ }$ \\
\hline Frame 3 & $\sqrt{ }$ & & & & $\sqrt{ }$ & & & & & $\sqrt{ }$ & & & & & & & $\sqrt{ }$ \\
\hline Frame 4 & $\sqrt{ }$ & & & & $\sqrt{ }$ & & & & $\sqrt{ }$ & & & & & & & & $\sqrt{ }$ \\
\hline Frame 5 & $\sqrt{ }$ & & & & $\sqrt{ }$ & & & & & & & & & $\sqrt{ }$ & & & $\sqrt{ }$ \\
\hline Frame 6 & $\sqrt{ }$ & & & & $\sqrt{ }$ & & & & & & & & & $\sqrt{ }$ & & & $\sqrt{ }$ \\
\hline
\end{tabular}

$$
\begin{aligned}
& \text { Bobot Total (Wtot) } \\
& =\text { Wobj } \times 2 \text { Wp } \times 2 \text { Wla } \times 2 \text { Wua } \times \text { Wt } \\
& =274,4+2(4,12)+2(11,66)+2(19,21) \\
& \quad+343 \\
& =687,37 \text { Newton } \\
& \text { Gaya tekan }=\text { Wtot } x \cos \theta 4-F A+F M \\
& =687,37 \text { Newton } \times \cos 83-(-68,41) \\
& \quad+2923,41 \text { Newton } \\
& =3180,52 \text { Newton }
\end{aligned}
$$

Dari hasil analisis gaya tekan setelah perbaikan maka perbandingan gaya tekanan antara sebelum dan setelah perbaikan dapat ditunjukkan perbedaannya pada Tabel 19.

\section{Analisis postur kerja ovako setelah perbaikan}

Setelah mengimplementasikan troli di lantai produksi, dilakukan kembali pengamatan melalui video terhadap operator dalam melakukan aktivitas loading.
Total frame yang diambil untuk dianalisis adalah enam frame. Dari Tabel 20 diperlihatkan bahwa semua postur punggung lurus. Posisi lengan berada di bawah bahu. Posisi kaki pada frame 5 dan frame 6 berjalan karena troli didorong oleh operator. Seluruh frame hasilnya diinput ke software Ergo Fellow. Hasil akhirnya dapat dilihat pada Tabel 21.

Tabel 21 menunjukkan level eksposur aktivitas pembebanan mengalami penurunan dari kategori 3 menjadi kategori 1 . Kategori 1 berarti postur tubuh dalam keadaan normal dan tidak memberikan pengaruh yang merugikan khususnya pada sistem muskuloskeletal. Akibatnya, tidak perlu tindakan korektif. Alhasil, operator yang bekerja di area laser mesin sudah terlindungi oleh kondisi ergonomis dan dapat bekerja dengan aman.

Berbeda dengan troli atau hand truck material handling yang dikembangkan dalam (Bintang \& Dewi, 2017), (Sokhibi et al., 2018), yang disainnya cenderung mendekati troli standar. Troli yang dikembangkan 
Tabel 21. Analisis Sebelum-Sesudah untuk Analisis OWAS untuk Pemuatan (Loading)

\begin{tabular}{ccc}
\hline Operator & Sebelum Perbaikan & Setelah Perbaikan \\
\hline Frame 1 & Kategori 3 & Kategori 1 \\
Frame 2 & Kategori 3 & Kategori 1 \\
Frame 3 & Kategori 3 & Kategori 1 \\
Frame 4 & Kategori 3 & Kategori 1 \\
Frame 5 & Kategori 3 & Kategori 1 \\
Frame 6 & Kategori 3 & Kategori 1 \\
\hline
\end{tabular}

dalam penelitian ini memiliki disain khusus yang mampu memegang material yang cukup berat dan berbentuk gelondongan kertas dengan bentuk yang melingkar atau melengkung. Desain troli yang dibuat mampu meminimalkan kemungkinan material terjatuh dari troli.

\section{Simpulan}

Sistem analisis postur kerja Ovako mengidentifikasi operator memiliki risiko gangguan muskuloskeletal pada area mesin laser perforator $50 \mathrm{di}$ PT XYZ. Dari hasil analisis, OWAS mengkategorikan bahwa aktivitas memuat (loading) masuk dalam kategori 3 yang merupakan efek berbahaya yang nyata pada sistem muskuloskeletal, terutama di punggung bawah. Untuk mengurangi gangguan muskuloskeletal pada kegiatan memuat maka dilakukan analisis gaya tekan untuk mengetahui mekanisme gaya tekan pada L5/S1 kemudian dilakukan perbaikan dengan menerapkan metode quality function deployment untuk konstruksi peralatan material handling troli. Hasilnya, gaya tekan total dapat direduksi sekitar $44,26 \%$ dari 7.186,22 Newton menjadi 3.180,52 Newton yang berada di bawah batas aman maksimum pada L5/ S1 yaitu pada kategori 1.

\section{Referensi}

Berlin, C., Adams, C., \& Chalmers University of Technology, SE. (2017). Production Ergonomics: Designing Work Systems to Support Optimal Human Performance. Ubiquity Press. https://doi.org/10.5334/bbe

Bintang, A. N., \& Dewi, S. K. (2017). Analisa Postur Kerja Menggunakan Metode OWAS dan RULA. Jurnal Teknik Industri, 18(1), 43. https://doi.org/10.22219/JTIUMM.Vol18.No1.43 $-54$

Chaffin, D. B., Andersson, G. B. J., \& Martin, B. J. (2006). Occupational Biomechanics (4th ed.). John Wiley \& Sons, Inc.

Christy, D. V. (2019). Ergonomics and Employee Engagement. International Journal of Mechanical Engineering and Technology (IJMET), 10(2), 5.

Fitriani, A., \& Purnomo, H. (2018). Perancangan dan Pengembangan Bed Shower Menggunakan Metode Quality Function Deployment (QFD) Berdasarkan Prinsip Ergonomi. Jurnal Sistem dan Manajemen Industri, 2(2), 85. https://doi.org/10.30656/jsmi.v2i2.629
GóMez-GaláN, M., PéRez-Alonso, J., CallejóN-Ferre, Á.-J., \& LóPez-MartíNez, J. (2017). Musculoskeletal disorders: OWAS review. INDUSTRIAL HEALTH, 55(4), 314-337. https://doi.org/10.2486/indhealth.2016-0191

Haripurna, A., \& Purnomo, H. (2017). Desain Perancangan Alat Penyaring Dalam Proses Pembuatan Tahu Dengan Metode Macro Ergonomic Analysis and Design (MEAD). Jurnal Ilmiah Teknik Industri, 16(1), 22. https://doi.org/10.23917/jiti.v16i1.3845

Kosasih, R. R., Martini, S., \& Rahayu, M. (2019). Perancangan Alat Bantu untuk Liquid Container Berdasarkan Penilaian Rapid Entire Body Assessment dan Washington State Checklist. Jurnal Sistem dan Manajemen Industri, 3(1), 10. https://doi.org/10.30656/jsmi.v3i1.1459

Lee, T.-H., \& Han, C.-S. (2013). Analysis of Working Postures at a Construction Site Using the OWAS Method. International Journal of Occupational Safety and Ergonomics, 19(2), 245-250. https://doi.org/10.1080/10803548.2013.1107698 3

Maurice, P., Malaisé, A., Amiot, C., Paris, N., Richard, G.-J., Rochel, O., \& Ivaldi, S. (2019). Human movement and ergonomics: An industry-oriented dataset for collaborative robotics. The International Journal of Robotics Research, 38(14), 1529-1537. https://doi.org/10.1177/0278364919882089

Safitri, D. M., Astriaty, A. R., \& Rizani, N. C. (2017). Human Reliability Assessment dengan Metode Human Error Assessment and Reduction Technique pada Operator Stasiun Shroud PT. X. Jurnal Rekayasa Sistem Industri, 4(1), 1. https://doi.org/10.26593/jrsi.v4i1.1388.1-7

Sari, F. P., Suhardi, B., \& Astuti, R. D. (2017). Penilaian Postur Kerja di Area Konstruksi CV. Valasindo dengan Metode Quick Exposure Check. PERFORMA: Media Ilmiah Teknik Industri, $16(2)$ https://doi.org/10.20961/performa.16.2.16980

Shorrock, S. T., \& Williams, C. A. (2016). Human factors and ergonomics methods in practice: Three fundamental constraints. Theoretical Issues in Ergonomics Science, 17(5-6), 468-482. https://doi.org/10.1080/1463922X.2016.1155240

Sokhibi, A., Alifiana, M. A., \& Ghozali, M. I. (2018). Perancangan Troli Ergonomi pada Aktivitas Pengangkutan Beras di Penggilingan Padi. 
Jurnal Sistem dan Manajemen Industri, 2(2), 111. https://doi.org/10.30656/jsmi.v2i2.840

Sokhibi, A., \& Primadasa, R. (2019). Analisis Resiko Musculosceletal Disorder Pada Tata Letak Lcd Proyektor Ruang Kuliah Fakultas Ekonomi \& Bisnis Universitas Muria Kudus. SPEKTRUM INDUSTRI $17(2)$, https://doi.org/10.12928/si.v17i2.13705

Theopilus, Y., Jonathan, W., \& Gustin, Y. (2018). Pengembangan Alat Bantu Material handling untuk Meminimasi Beban Kerja Operator Produksi Crank Case di PT.X. Jurnal Rekayasa
Sistem Industri, 7(2), https://doi.org/10.26593/jrsi.v7i2.2832.85-98

Wahyuniardi, R., \& Reyhanandar, D. M. (2018). Penilaian Postur Operator Dan Perbaikan Sistem Kerja Dengan Metode Rula Dan Reba (studi Kasus). J@ti Undip: Jurnal Teknik Industri, 13(1), 45. https://doi.org/10.14710/jati.13.1.4550

Yassierli, Y., Irawan, D. A. A., \& Pratiwi, K. K. (2018). Pengaruh Keergonomisan Stasiun Komputer Game Net Pada Risiko Gangguan Otot-Rangka. J@ti Undip : Jurnal Teknik Industri, 13(2), 109. https://doi.org/10.14710/jati.13.2.109-116 